\title{
Lipoprotein (a) Status and Effect of Laparoscopic Cholecystectomy on it in Bangladeshi Patients with Cholelithiasis
}

\author{
Giasuddin ASM $^{1 *}$, Khadija Akther Jhuma ${ }^{2}$, Md Abdul Mobin Choudhury ${ }^{2}$, Mujibul Haq AM ${ }^{2}$ \\ ${ }^{1}$ Medical Research Unit (MRU), MHWT, Dhaka-1230, Bangladesh \\ ${ }^{2}$ Medical College for Women and Hospital, Dhaka-1230, Bangladesh
}

"Corresponding author: Dr. Giasuddin ASM, MSc PhD PGD CSciFIBMS MNYAS, Professor of Biochemistry and Immunology, Director, Medical Research Unit (MRU), MHWT, Uttara Model Town Dhaka-1230, Bangladesh, Tel: +8801787657685/+880-2-58953939; E-mail: mru.mhwt@gmail.com

Received date: Nov 05, 2016; Accepted date: Nov 23, 2016; Published date: Nov 30, 2016

Copyright: @ 2016 Giasuddin ASM, et al. This is an open-access article distributed under the terms of the Creative Commons Attribution License, which permits unrestricted use, distribution, and reproduction in any medium, provided the original author and source are credited.

\begin{abstract}
Objective: Although it was reported that cholecystectomy had complex impact on lipid profile in cholelithiasis, lipoprotein (a) [Lp(a)] was not studied. The present study was therefore conducted on serum $L p(a)$ status in Bangladeshi patients with cholelithiasis and effect of cholecystectomy on it.
\end{abstract}

Patients and Methods: Adult patients $(n=44)$ with cholelithiasis and 30 normal controls (NC) were included in the study. The blood sample was taken from fasting patients before cholecystectomy $\left(\right.$ Serum- $\mathrm{I}^{0}$ ), gall bladder bile sample during cholecystectomy (Bile- $\left.I^{0}\right)$ and blood sample again after 2-3 months at follow-up $\left(\right.$ Serum- $\left.I^{0}\right)$ and from fasting NC subjects. $\mathrm{Lp}(\mathrm{a})$ level was quantitated in serum and bile by immunoturbidimetric method using commercially available research kit. The results were compared statistically by ANOVA, Student's t-test and Chisquared test using SPSS programme.

Results: The $\mathrm{Lp}(\mathrm{a})$ status (mg/dl, Mean $\pm \mathrm{SD})$ in controls and patients and their statistical analysis revealed that $\mathrm{Lp}$ (a) was much higher in patients compared to controls (NC: $29.07 \pm 14.1$, Patients Serum- ${ }^{0}$ : $290.84 \pm 110.93$, Patients Bile-10 : $37.12 \pm 28.61$, Patients Serum-II0: $203.70 \pm 90.13)(P<0.001)$. Lp(a) was lowered after cholecystectomy, but remained elevated in patients Serum- $I^{0}$ compared to NC significantly $(P<0.001)$. No significant difference was observed for $L p(a)$ levels between $N C$ and patients Bile- $I^{0}(P=0.173)$. The proportions of patients for Serum $-1^{0}$, Bile- $I^{0}$ and Serum- $-I^{0}$ with $\mathrm{Lp}(\mathrm{a})$ levels above and within normal limits and their statistical analyses showed significant associations $(P<0.001)$

Conclusions: Cholelithiasis had complex impact on $L p(a)$ status indicating a special function of gall bladder relevant to its metabolism. Further studies are warranted.

Keywords: Lipoprotein (a); Cholelithiasis; Cholecystectomy

\section{Introduction}

One of the common gastrointestinal disorders prevalent in about $10-15 \%$ of adults in the developing countries is Cholelithiasis (gallstone disease) $[1,2]$. Surgical removal of the gallbladder and gallstones, i.e. cholecystectomy is the treatment of choice currently [3,4]. Studies over 30 years ago showed that more than $50 \%$ of patients with gallstone would have lipid disorder [1,5].

The pathogenesis of cholesterol gallstone is widely accepted as an altered lipid metabolism, because of which there is a relative increase in the cholesterol levels compared to other lipids secreted by the liver into the bile $[1,4,5]$. Many factors including nucleation of cholesterol crystals, binding together of these crystals with mucin and hypomotility of the gallbladder play an important role in gallstone formation [6-8]. The molecular events that underlie these processes have not been understood completely, although association between gallstones and altered lipid profile has been shown in some studies $[4,9,10]$.

Lipoprotein (a) $[\mathrm{Lp}(\mathrm{a})]$ has been implicated as a probable cause for atherosclerosis $[3,4]$. Since its identification by Norwegian geneticist
Kare Berg in 1963, Lp(a) has become a focus of research interest owing to the results of case-control and prospective studies linking elevated plasma levels of this lipoprotein with the development of coronary artery disease (CAD) $[5,6]$. Based on the similarity of $\mathrm{Lp}(\mathrm{a})$ to both low density lipoprotein (LDL) and plasminogen, it has been hypothesized that the function of this lipoprotein may represent a link between the fields of atherosclerosis and thrombosis [6-8].

Apolipoprotein A1 (Apo A1), ApoE, CETP and Mucin have been implicated with cholelithiasis In some studies [4,11-13]. HDL-C, VLDL and Lp(a) were implicated with coronary artery disease(CAD), diabetes mellitus, polycystic ovarian syndrome (POS) [3,14-17]. Higher levels of Lp(a), Leptin, ApoB and malondialdehyde (MDA) and lower levels of HDL-C and paraoxonase activity were reported to be associated in cholelithiasis $[18,19]$.

The fact that plasma $\mathrm{Lp}(\mathrm{a})$ levels are largely genetically determined and vary widely among different ethnic groups adds scientific interest to the ongoing research on this enigmatic molecule. Only limited studies have been reported on serum levels of $\mathrm{Lp}(\mathrm{a})$ in some populations including Indian subcontinent [20,21]. Although determination of the function of $\operatorname{Lp}(\mathrm{a})$ in vivo remains elusive, serum $\mathrm{Lp}$ (a) levels were reported to be elevated in DM and an independent risk factor for CAD in DM, particularly non-insulin dependent DM 
(NIDDM) patients [22-24]. However, these results were variable and need confirmation by further studies in cholelithiasis patients.

Literature review indicated that no study had been done or reported involving cholelithiasis patients from Bangladesh, although two studies reported not relevant to lipid metabolism were on day care laparoscopic cholecystectomy (LC) and intra-operative flexible choledochoscopy (IFC) in Bangladeshi patients [25,26]. We have therefore decided to investigate in phases the various aspects of lipid profile and their metabolism in cholelithiasis patients followed by cholecystectomy at Medical Research Unit (MRU), MHWT, Dhaka, Bangladesh. Previously, we reported the results on lipid profile i.e. triglyceride (TG), total cholesterol (TC), low density lipoproteincholesterol (LDL-C) and high density lipoprotein-cholesterol (HDL-C) levels in serum and bile of cholelithiasis patients before cholecystectomy $\left(\mathrm{I}^{0}\right)$ and after cholecystectomy $\left(\mathrm{II}^{0}\right)$ and in normal control subjects [27]. In the present article, we have reported results of the study on $\operatorname{Lp}(\mathrm{a})$ status in serum and bile of cholelithiasis patients preoperatively and postoperatively at MRU, MHWT Dhaka, Bangladesh.

\section{Patients and Methods}

Adult patients with cholelithiasis (Number: 44, Gender: 8 males, 36 females; Age range: $25-65$ years, Mean age \pm SD: $45.5 \pm 12.2$ years) with cholelithiasis (gall stone disease) and healthy adults as normal controls (Number: 30, Gender: 12 males, 18 females; Age range: 28-60 years; Mean age \pm SD: $42.5 \pm 10.5$ years) were included in the present case-control prospective interventional study.

The patients with gallstone disease (cholelithiasis) were diagnosed as having cholelithiasis according to standard clinical and laboratory criteria as practiced in hospital and patients not fulfilling the criteria for our study on cholelithiasis were excluded [27-29]. The diagnostic algorithm for cholelithiasis were taking medical history, clinical examination, ultrasonogram (USG) of hepato-biliary system and pancreas and routine laboratory investigations including liver function tests (LFTs). After obtaining consent, patient's demographic details and clinical findings such as pain (severity, duration, location), Murphy's sign, USG, etc were recorded as per 'PROFORMA' at diagnosis.

The fasting blood samples were taken at diagnosis before laparoscopic cholecystectomy, and conducted routine laboratory tests. The serum separated was aliquoted and stored frozen at $-300^{\circ} \mathrm{C}$ to $-80^{\circ} \mathrm{C}$ as first degree serum sample $\left(\mathrm{I}^{\circ}\right)$. At the time of laparoscopic cholecystectomy, gallbladder bile was also collected from the same patient, centrifuged, aliquoted and stored frozen at $-300^{\circ} \mathrm{C}$ to $-80^{\circ} \mathrm{C}$ as first degree bile sample $\left(\mathrm{I}^{\circ}\right)$.

After Cholecystectomy, treatments/medications were given as required for the patients. After 2-3 months at follow-up, fasting blood samples were taken again from the same patient, serum separated, aliquoted and stored frozen at $-300^{\circ} \mathrm{C}$ to $-80^{\circ} \mathrm{C}$ as second degree serum samples $\left(\mathrm{II}^{\circ}\right)$ until analyzed for the lipid profile (i.e. TG, TC, HDL-C, LDL-C) and Lp(a). All quantitative estimations in serum and bile were made by standard medical laboratory methods for lipid profile and $\mathrm{Lp}(\mathrm{a})$ using standard diagnostics kits from internationally reputed companies and LDL-C calculated by Friedwald formula [27,30].

The results of laboratory analyses in biological specimens of patients $\left(\mathrm{I}^{\circ}, \mathrm{II}^{\circ}\right)$ and controls (NC) for $\mathrm{Lp}(\mathrm{a})$ were compared statistically by ANOVA, Student's t-test and Chi-squared test using SPSS programme in computer [31]. The results of our study on the other lipid profile, i.e.
TG, TC, HDL-C, LDL-C were reported previously [27]. In the present article, the results on $\mathrm{Lp}(\mathrm{a})$ status and effect of laparoscopic cholecystectomy on it in Bangladeshi Patients with Cholelithiasis are reported.

\section{Results}

The Lp(a) status in our study subjects and their statistical analyses are stated in Table 1 . Lp(a) was much elevated in patients Serum-I0 compared to $\mathrm{NC}(\mathrm{P}<0.001)$. This was lowered after laparoscopic cholecystectomy, but remained elevated in patients Serum- $\mathrm{II}^{0}$ compared to NC significantly $(\mathrm{P}<0.001)$.

No significant difference was observed for $\operatorname{Lp}(\mathrm{a})$ levels between NC and patients Bile- $\mathrm{I}^{0}(\mathrm{P}=0.173)$. The proportion of patients for Serum$\mathrm{I}^{0}$, Bile- $\mathrm{I}^{0}$ and Serum- $\mathrm{II}^{0}$ with $\mathrm{Lp}(\mathrm{a})$ levels above and within normal limits and their statistical analyses are stated in Tables 2 and 3 respectively.

\section{Discussion}

Our findings in Bangladeshi patients with cholelithiasis that serum Lp(a) level was significantly elevated and that significantly larger proportion of patients had higher serum Lp(a) levels were consistent with some reports in the literature from other countries $[2,7,11]$. However, it should be noted that cut off value of $30.0 \mathrm{mg} / \mathrm{dl}$ for the higher end of the $95 \%$ (normal) range reported in the literature is not absolute as it varied from study to study.

The probable factors responsible for variations in plasma/serum $\mathrm{Lp}$ (a) level could be that different studies used different plasma/serum storage temperatures $\left(-200^{\circ} \mathrm{C},-300^{\circ} \mathrm{C},-800^{\circ} \mathrm{C}\right)$ for various time periods (up to 1 year, 7 years, $15-18$ years) prior to analysis by assay methods as varied as radioimmunoassay, enzyme immunoassay, radial immunodiffusion, immunoturbidimetry, etc. [17-20]. Secondly, plasma/serum $\operatorname{Lp}(\mathrm{a})$ level is genetically determined and it varies according to populations, ethnic groups and geographical regions of the world $[9,10]$.

The incidence of cholesterol gallstones, although less in our male population, was probably related to sedentary lifestyle and consumption of diet particularly rich in animal fats, refined sugars and poor in vegetable fats and fibers, all of which are significant risk factors for gallstone formation [32-34]. The consumption of a high calorie diet in the west is more common and is clearly an important factor in the formation of cholesterol gallstones. This trend has gradually spread to the East Asian countries, with dietary habits becoming unhealthier [34-36].

Elevated plasma/serum level of $\mathrm{Lp}(\mathrm{a})$ has been linked with CAD $[5,6,17,18]$. Another important aspect is that baseline $\mathrm{Lp}(\mathrm{a})$ levels were not measured in cases and controls in many follow-up studies with cholesterol lowering therapy. However, some studies showed that cholestyramine treatment was not effective in lowering $\operatorname{Lp}(\mathrm{a})$ levels, although cholesterol level was reported to be reduced $[15,18,24]$.

In recent overviews on the management of primary hyperlipidemia by statins, serum $L p(a)$ level and its reduction were not mentioned and considered in the discussion [25-27]. Even the updated National Cholesterol Education Programme (NCEP) report, USA published in July 2004 discussed and debated LDL-C only and no consideration for Lp(a) level was suggested in the NCEP report $[27,28]$. 
Citation: Giasuddin ASM, Jhuma KA, Choudhury AM, Haq AMM (2016) Lipoprotein (a) Status and Effect of Laparoscopic Cholecystectomy on it in Bangladeshi Patients with Cholelithiasis. J Metabolic Synd 5: 216. doi:10.4172/ 2167-0943.1000216

Page 3 of 5

\begin{tabular}{|c|c|c|c|c|}
\hline \multirow{2}{*}{ Serum and Bile Lp(a) Level (mg/dl)* } & \multicolumn{4}{|c|}{ Subjects and Biological Specimens } \\
\hline & Normal Controls(NC) & Patients (Serum $-1^{0}$ ) & Patients (Bile-10) & Patients (Serum- $I^{0}$ ) \\
\hline Observed Range & $9.51-58.24$ & $119.01-582.01$ & $12.01-125.01$ & $65.0-391.6$ \\
\hline Mean \pm SD & $29.07 \pm 14.17$ & $290.84 \pm 110.93$ & $37.12 \pm 28.61$ & $203.70 \pm 90.13$ \\
\hline (SE) & $(2.59)$ & $(16.72)$ & $(5.22)$ & $(15.46)$ \\
\hline $95 \% \mathrm{CIM}$ & $23.78-34.36$ & $257.12-324.57$ & $26.43-47.80$ & $172.25-235.14$ \\
\hline Statistical Analysis* (Groups Compared) & \multicolumn{4}{|c|}{ Statistical Parameters } \\
\hline ANOVA $\left(\mathrm{NC}\right.$, Serum $-1^{0}$, Bile- $1^{0}$, Serum- $\left.\|^{0}\right)$ & \multicolumn{4}{|c|}{$d f=3,134, F=96.41, p<0.001^{*}$} \\
\hline \multicolumn{5}{|l|}{ Student's t-test } \\
\hline NC vs Serum $-1^{0}$ & \multicolumn{4}{|l|}{$d f=72, t=-12.83, p<0.001^{*}$} \\
\hline $\mathrm{NC}$ vs Serum- $I^{0}$ & \multicolumn{4}{|l|}{$\mathrm{df}=62, \mathrm{t}=-10.49, \mathrm{p}<0.001^{*}$} \\
\hline NC vs Bile- $I^{0}$ & \multicolumn{4}{|c|}{$\mathrm{df}=58, \mathrm{t}=-1.381, \mathrm{p}=0.173(\mathrm{NS})$} \\
\hline Bile- $1^{0}$ vs Serum $-1^{0}$ & \multicolumn{4}{|c|}{$\mathrm{df}=72, \mathrm{t}=-12.23, \mathrm{p}<0.001^{*}$} \\
\hline Bile- $I^{0}$ vs Serum- $\|^{0}$ & \multicolumn{4}{|l|}{$d f=62, t=-9.69, p<0.001^{*}$} \\
\hline Serum $-1^{0}$ vs Serum- $\| I^{0}$ & \multicolumn{4}{|l|}{$\mathrm{df}=76, \mathrm{t}=3.73, \mathrm{p}<0.001^{*}$} \\
\hline
\end{tabular}

Table 1: Lp(a) levels in Serum and bile before cholecystectomy (Serum- $\mathrm{I}^{0}$, Bile- $\left.\mathrm{I}^{0}\right)$ and after cholecystectomy $\left(\right.$ Serum- $\left.\mathrm{II}^{0}\right)$ and their statistical analyses.

Lp(a) may compete with plasminogen, because of its sequence homology, for binding to fibrin and impair fibrinolysis. High levels of $\mathrm{Lp}(\mathrm{a})$ in serum may, therefore represent a potential source of antifibrinolytic activity [11,29]. In addition to this antifibrinolytic activity, high concentration of $\operatorname{Lp}(\mathrm{a})$ also suppresses the activity of transforming growth factor- $\beta$ (TGF- $\beta$ ) which has the potential to inhibit the proliferation of endothelial cells and smooth muscle cells.

This probably causes increased proliferation of the vascular endothelial cells and smooth muscle cells resulting in the progression of atherosclerosis $[11,30]$. So, treatment of hypercholesterolemia with cholestyramine/statins may reduce but cannot abolish progression of atherogenesis and hence risk of long term complications in DM and CAD.

These clearly indicate that in the studies with cholesterol lowering drugs such as cholestyramine/ statins, serum Lp(a) levels should be followed up as well. In addition, recent reports suggested that TGF- $\beta$ is involved in ultra structural tissue changes in patients with cholelithiasis and subsequently in gallbladder fibrosis leading to hypomotility which may be an important step in gallbladder dysfunction in this disorder $[37,38]$.

The inhibition of TGF- $\beta$ by higher levels of $\mathrm{Lp}(\mathrm{a})$, therefore, may be a probable protective mechanism against gallstone disease. Thus, it is equally important to investigate whether $\operatorname{Lp}(\mathrm{a})$ has any protective role against cholelithiasis contrary to atherosclerosis.

Apolipoprotein A1 (Apo A1), Apo E, CETP and mucin have been implicated with cholelithiasis in some studies [4,11-13]. In a recent study, it was reported that cholelithiasis patients have higher leptin levels and altered lipoprotein profile, with increased $\mathrm{Lp}(\mathrm{a})$ and Apo(B)levels and decreased ApoA-1 levels [19].

Another recent study showed that symptomatic cholelithiasis patients have increased malondialdehyde (MDA) levels indicating lipid peroxidation and decreased antioxidant capacity [18]. These changes in plasma lipids are, therefore, likely to have significant effect in the induction of gallstone disease and subsequently CAD postoperatively in patients with cholecystectomy. Abnormalities in lipids and apolipoproteins metabolism may, however, arise from a combination of various factors such as excess dietary cholesterol/fat, obesity, diabetes and genetic factors $[4,39]$.

Some prominent facts known about $\operatorname{Lp}(\mathrm{a})$ are that it is a genetically determined particle containing a ApoB-100 linked to Apo(a), cholestyramine treatment is not effective in lowering serum Lp(a) level and $\mathrm{Lp}(\mathrm{a})$ has structural homology with plasminogen implicating in atherosclerosis and CADs.

In conclusion, however, it was evident from our results that changes in $\mathrm{Lp}(\mathrm{a})$ in cholelithiasis were significant and interesting, but a complex one and laparoscopic cholecystectomy did have significant impact on them.

These changes in $\mathrm{Lp}(\mathrm{a})$ is of crucial importance and the gallbladder may have a definitive role in it leading to development of gallstone disease i.e. cholelithiasis. Thus, incorporation of $\mathrm{Lp}(\mathrm{a})$ routinely in lipid profile analysis would be useful in identifying high risk patients and follow-up. Further studies are therefore warranted investigating several aspects of lipids, $\operatorname{Lp}(\mathrm{a})$, and apolipoproteins metabolism in cholelithiasis patients followed by cholecystectomy. 
Citation: Giasuddin ASM, Jhuma KA, Choudhury AM, Haq AMM (2016) Lipoprotein (a) Status and Effect of Laparoscopic Cholecystectomy on it in Bangladeshi Patients with Cholelithiasis. J Metabolic Synd 5: 216. doi:10.4172/ 2167-0943.1000216

Page 4 of 5

\begin{tabular}{|c|c|c|c|c|}
\hline \multirow{2}{*}{$\begin{array}{l}\text { Lp(a) level } \\
\text { (mg/L) }\end{array}$} & \multicolumn{3}{|c|}{ Subjects } & \multirow{2}{*}{$\begin{array}{l}\text { Chi-squared } \\
\left(x^{2}\right) \text { test }\end{array}$} \\
\hline & NCs & Serum & Total & \\
\hline$\leq 57.5$ & 29 & 1 & 30 & $x^{2}=62.08$ \\
\hline$>57.5$ & 1 & 43 & 44 & $d f=1$ \\
\hline Total: & 30 & 44 & 74 & $p<0.001^{*}$ \\
\hline \multicolumn{5}{|c|}{ NCs: Normal control subjects; Serum-1 $1^{0}$ : Patients Serum-10 } \\
\hline \multirow{2}{*}{$\begin{array}{l}\text { Lp(a) level } \\
\text { (mg/L) }\end{array}$} & \multicolumn{3}{|c|}{ Subjects } & $\begin{array}{l}\text { Chi-squared } \\
\left(x^{2}\right) \text { test }\end{array}$ \\
\hline & NCs & Bile-1 ${ }^{0}$ & Total & \\
\hline$\leq 57.5$ & 29 & 20 & 49 & $x^{2}=7.124$ \\
\hline$>57.5$ & 1 & 10 & 11 & $d f=1$ \\
\hline Total: & 30 & 30 & 60 & $p=0.007^{*}$ \\
\hline
\end{tabular}

NCs: Normal Control Subjects; Bile-10: Patients Bile-10

\begin{tabular}{|l|l|l|l|l|}
\hline \multirow{2}{*}{$\begin{array}{l}\text { Lp(a) level } \\
(\mathrm{mg} / \mathrm{L})\end{array}$} & \multicolumn{2}{|l|}{ Subjects } & $\begin{array}{l}\text { Chi-squared } \\
\left(\mathrm{X}^{2}\right) \text { test }\end{array}$ \\
\cline { 2 - 5 } & NCs & Serum-II & Total & \\
\hline$\leq 57.5$ & 29 & 2 & 31 & $\mathrm{X}^{2}=49.02$ \\
\hline$>57.5$ & 1 & 32 & 33 & $\mathrm{df}=1$ \\
\hline Total: & 30 & 34 & 64 & $\mathrm{p}<0.001^{*}$ \\
\hline
\end{tabular}

NCs: Normal Control Subjects; Serum-II ${ }^{0}$ Patients Serum- $I^{0}$

Table 2: Proportion of cholelithiasis patients with Lp(a) levels above and within normal limit and their statistical analysis by Chi-squared $\left(\chi^{2}\right)$ test.

\begin{tabular}{|c|c|c|c|c|c|}
\hline \multirow{2}{*}{$\begin{array}{l}\text { Lp(a) level } \\
\text { (mg/L) }\end{array}$} & \multicolumn{4}{|l|}{ Subjects } & \multirow{2}{*}{$\begin{array}{l}\text { Chi-squared } \\
\left(x^{2}\right) \text { test }\end{array}$} \\
\hline & Serum $-1^{0}$ & Bile-- ${ }^{0}$ & $\begin{array}{l}\text { Serum- } \\
\|^{0}\end{array}$ & Total & \\
\hline$\leq 57.5$ & 1 & 20 & 2 & 23 & $x^{2}=51.16$ \\
\hline$>57.5$ & 43 & 10 & 32 & 85 & $d f=2$ \\
\hline Total: & 44 & 30 & 34 & 108 & $p<0.001^{*}$ \\
\hline
\end{tabular}

Table 3: Proportion of cholelithiasis patients with Serum- $\mathrm{I}^{0}$, Bile- $\mathrm{I}^{0}$ and Serum-II ${ }^{0} \mathrm{Lp}(\mathrm{a})$ levels above and within normal limit and their statistical analysis by Chi squared $\left(\chi^{2}\right)$ test.

\section{Funding Details}

The work was supported by The Medical and Health Welfare Trust (MHWT), Plot-4 Road-9 Sector-1, Uttara Model Town, Dhaka-1230, Bangladesh.

\section{Acknowledgements}

The authors appreciate Mr. Taposh K Datta, Medical Technologist, for helping with laboratory analysis, Mr Shohag MN Ali for computer composing the manuscript and Mr. AHM Salman for statistical analysis. The authors gratefully acknowledge the generous financial support of The Medical and Health Welfare Trust (MHWT), Dhaka, Bangladesh for this research project.

\section{References}

1. James HG, Kenneth RM, Scot LF (1996) Current diagnosis and treatment in gastroenterology, Int. ed; Connecticut: Appletin and Lange.

2. Everhart JE, Khare M, Hill M, Maurer KR (1999) Prevalence and ethnic differences in gallbladder disease in the United States. Gastroenterology 117: 632-639.

3. Batajoo H, Hazra NK (2013) Analysis of serum lipid profile in cholelithiasis patients. J Nepal Health Res Counc 11: 53-55.

4. Rao PJ, Jarari A, E1 Awami H, Patil TN (2012) Lipid profile in bile and serum of cholelithiasis patients - A Comparative study. J Basic Med \& Allied Sci 1: 15-21.

5. Apstein MD, Carey MC (1996) Pathogenesis of cholesterol gallstones: a parsimonious hypothesis. Eur J Clin Invest 26: 343-352.

6. Channa NA (2008) Gallstone disease: a review. Pak Arm Forces Med J 58: 197-208.

7. Tandon RK (1990) Current development in the pathogenesis of gallstones. Trop Gastroenterol 11: 130-139.

8. Portincasa P, Di Ciaula A, Vendemiale G, Palmieri V, Moschetta A, et al. (2000) Gallbladder motility and cholesterol crystallization in bile from patients with pigment and cholesterol gallstones. Eur J Clin Invest 30: 317-324.

9. Malik AA, Wani ML, Tak SI, Irshad I, Ul-Hassan N (2011) Association of dyslipidaemia with cholilithiasis and effect of cholecystectomy on the same. Int J Surg 9: 641-642.

10. Skill NJ, Scott RE, Wu J, Maluffio MA (2011) Hepatocellular carcinoma associated lipid metabolism reprogramming. J Surg Res 169: 51-56.

11. Hasegawa T, Makino I (1995) Measurement of apolipoprotein A1 in cholesterol gallstones and gallbladder bile of patients with gallstones. J Gastroenterol 30: 96-102.

12. Juvonen T, Kervinen K, Kairaluoma MI, Kesäniemi YA (1995) Effect of cholecystectomy on plasma lipid and lipoprotein levels. Hepatogastroenterology 42: 377-382.

13. Pinheiro-Júnior S, Pinhel MA, Nakazone MA, Pinheiro A, Amorim GF, et al. (2012) Effect of genetic variants related to lipid metabolism as risk factors for cholelithiasis after bariatric surgery in Brazilian population. Obes Surg 22: 623-633.

14. Danesh J, Collins R, Peto R (2000) Lipoprotein(a) and coronary heart disease. Meta-analysis of prospective studies. Circulation 102: 1082-1085.

15. Barghash NA, Elewa SM, Hamdi EA, Barghash AA, El Dine R (2004) Role of plasma homocysteine and lipoprotein (a) in coronary artery disease. Br J Biomed Sci 61: 78-83.

16. Giasuddin ASM, Jhuma KA, Mujibul Haq AM (2008) Lipoprotein (a) status in Bangladeshi patients with diabetes mellitus. J Med Coll Women Hosp 6: 74-82.

17. Haq AMM, Giasuddin ASM, Huque MM (2011) Serum total homocysteine and lipoprotein (a) levels in acute myocardial infarction and their response to treatment with vitamins. J Coll Physicians Surg Pak 21: $266-270$.

18. Atamer A, Kurdas-Ovunc AO, Yesil A, Atamer Y (2014) Evaluation of paraoxonase, malondialdehyde, and lipoprotein levels in patients with asymptomatic cholelithiasis. Saudi J Gastroenterol 20: 66-73.

19. Saraç S, Atamer A, Atamer Y, Can AS, Bilici A, et al. (2015) Leptin levels and lipoprotein profiles in patients with cholelithiasis. J Int Med Res 43: 385-392. 
Citation: Giasuddin ASM, Jhuma KA, Choudhury AM, Haq AMM (2016) Lipoprotein (a) Status and Effect of Laparoscopic Cholecystectomy on it in Bangladeshi Patients with Cholelithiasis. J Metabolic Synd 5: 216. doi:10.4172/ 2167-0943.1000216

Page 5 of 5

20. Devanapalli B, Lee S, Mahajan D, Bermingham M (2002) Lipoprotein (a) in an immigrant Indian population sample in Australia. Br J Biomed Sci 59: 119-122.

21. Gaw A, Brown EA, Gourlay CW, Bell MA (2000) Analytical performance of the Genzyme LipoPro Lp(a) kit for plasma lipoprotein(a)-cholesterol assay. Br J Biomed Sci 57: 13-18.

22. Powers AC (2005) Diabetes mellitus. In: Kasper DL, Fauci AS, Longo DL, Braunwald E, Hauser SL, Jameson JL (Editors). Harrison's Principals of Internal Medicine (16th Edn) New York: McGraw-Hill.

23. Marcovina SM, Koschinsky ML (1998) Lipoprotein(a) as a risk factor for coronary artery disease. Am J Cardiol 82: 57U-66U.

24. Berg K (1963) A New serum type system in man--The LP system. Acta Pathol Microbiol Scand 59: 369-382.

25. Khan MH, Khan AW, Aziz MM, Rabbi MA (2012) Day case Laparoscopic Cholecystectomy: experience at the Bangabandhu Sheikh Mujib Medical University. Mymenshingh Med J 21: 485-489.

26. Ahmed T, Alam MT, Ahmed SU, Jahan M (2012) Role of intraoperative flexible Choledochoscopy in calculous biliary tract disease. Mymensingh Med J 21: 462-468.

27. Haq AMM, Giasuddin ASM, Jhuma KA, Choudhury MAM (2015) Effect of cholecystectomy on lipidprofile in Bangladeshi patients with cholelithiasis. J Metabolic Synd 5.

28. Anstee QM, Jones DEJ (2014) Liver and biliary tract disease. Davidson's Principles \& Practice of Medicine (22nd Edn) Edinburgh: Churchill Livingstone (Elsevier) 2014: 921-88.

29. Cuschieri SA (2002) Disorders of the biliary tract. Essential Surgical Practice (4th Edn) London: Arnold.

30. Remaley AT, Rifai N, Warnick GR (2015) Lipids, Lipoprotein apolipoproteins and other cardiac risk factors. In: Burtis CA, Bruns DE.
(Editors). Tietz Fundamentals of Clinical Chemistry and Molecular Diagnostics (7th Edn), St. Louise, Missouri: Elsevier Inc (Saunders), USA.

31. Kirkwood BR, Sterne JAC (2008) Essential Medical Statistics, 2nd Edition (Reprinted); Oxford:Blackwell Science Ltd.

32. Cuevas A, Miquel JF, Reyes MS, Zanlungo S, Nervi F (2004) Diet as a risk factor for cholesterol gallstone disease. J Am Coll Nutr 23: 187-196.

33. Misciagna G, Centonze S, Leoci C, Guerra V, Cisternino AM, et al. (1999) Diet, physical activity, and gallstones--a population-based, case-control study in southern Italy. Am J Clin Nutr 69: 120-126.

34. Tsai CJ, Leitzmann MF, Willett WC, Giovannucci EL (2004) The effect of long-term intake of cis unsaturated fats on the risk for gallstone disease in men: a prospective cohort study. Ann Intern Med 141: 514-522.

35. Tsunoda K, Shirai Y, Hatakeyama K (2004) Prevalence of cholesterol gallstones positively correlates with per capita daily calorie intake. Hepatogastroenterology 51: 1271-1274.

36. Aulakh R, Mohan H, Attri AK, Kaur J, Punia RP (2007) A comparative study of serum lipid profile and gallstone disease. Indian J Pathol Microbiol 50: 308-312.

37. Köninger J, di Mola FF, Di Sebastiano P, Gardini A, Brigstock DR, et al. (2005) Transforming growth factor-beta pathway is activated in cholecystolithiasis. Langenbecks Arch Surg 390: 21-28.

38. Ebadi P, Daneshmandi S, Ghasemi A, Karimi MH (2013) Cytokine single nucleotide polymorphisms in patients' with gallstone: dose TGF- ${ }^{2}$ gene variants affect gallstone formation? Mol Biol Rep 40: 6256-6260.

39. Weiss KM, Ferrell RE, Hanis CL, Styne PN (1984) Genetics and epidemiology of gallbladder disease in New World native peoples. Am J Hum Genet 36: 1259-1278. 